\title{
Description of Polystyrenella longa gen. nov., sp. nov., isolated from polystyrene particles incubated in the Baltic Sea
}

\author{
Stijn H. Peeters • Sandra Wiegand • Nicolai Kallscheuer • Mareike Jogler • \\ Anja Heuer • Mike S. M. Jetten • Christian Boedeker • Manfred Rohde • \\ Christian Jogler
}

Received: 28 January 2020/Accepted: 15 March 2020/Published online: 1 April 2020

(C) The Author(s) 2020

\begin{abstract}
Planctomycetes occur in almost all aquatic ecosystems on earth. They have a remarkable cell biology, and members of the orders Planctomycetales and Pirellulales feature cell division by polar budding, perform a lifestyle switch from sessile to motile cells and have an enlarged periplasmic space. Here, we characterise a novel planctomycetal strain, Pla1 $10^{\mathrm{T}}$, isolated from the surface of polystyrene particles incubated in the Baltic Sea. After phylogenetic analysis, the strain could be placed in the family Planctomycetaceae. Strain Pla $110^{\mathrm{T}}$ performs cell division by budding, has crateriform structures and grows in
\end{abstract}

S. H. Peeters - N. Kallscheuer - M. S. M. Jetten ·

C. Jogler $(\square)$

Department of Microbiology, Radboud Universiteit,

Nijmegen, The Netherlands

e-mail: christian@jogler.de

S. Wiegand

Institute for Biological Interfaces 5, Karlsruhe Institute of

Technology, Eggenstein-Leopoldshafen, Germany

M. Jogler · C. Jogler

Department of Microbial Interactions, Institute of Microbiology, Friedrich Schiller University, Jena, Germany

A. Heuer - C. Boedeker

Leibniz Institute DSMZ, Brunswick, Germany

M. Rohde

Central Facility for Microscopy, Helmholtz Centre for Infection Research, HZI, Brunswick, Germany aggregates or rosettes. The strain is a chemoheterotroph, grows under mesophilic and neutrophilic conditions, and exhibited a doubling time of $21 \mathrm{~h}$. Based on our phylogenetic and morphological characterisation, strain Pla110 ${ }^{\mathrm{T}}$ (DSM $103387^{\mathrm{T}}=\mathrm{LMG}$ $29693^{\mathrm{T}}$ ) is concluded to represent a novel species belonging to a novel genus, for which we propose the name Polystyrenella longa gen. nov., sp. nov.

Keywords Marine bacteria Planctomycetes . Planctomycetaceae $\cdot$ Marine biofilms · Microplastic particles

\section{Introduction}

Planctomycetes are bacteria with a Gram-negative cell envelope architecture belonging to the PVC superphylum, along with Verrucomicrobia, Lentisphaerae, Kiritimatiellaeota, Candidatus Omnitrophica and $\mathrm{Ch}$ lamydiae. Many representatives of this superphylum have major medical and biotechnological relevance (Wagner and Horn 2006), and can play key roles in global biogeochemical cycles (Peeters and van Niftrik 2018; Strous et al. 1999; Wiegand et al. 2018).

Planctomycetes are found in many environments, e.g. on (marine) algae (Bengtsson and Øvreås 2010; Bengtsson et al. 2012; Bondoso et al. 2014, 2015, 2017; Lage and Bondoso 2014; Vollmers et al. 2017), in peat bogs in northern wetlands 
(Kulichevskaya et al. 2012) or in hot springs (Slobodkina et al. 2015). They are assumed to metabolise complex carbon substrates released by biotic surfaces (Frank et al. 2014; Jeske et al. 2013; Lachnit et al. 2013; Wiegand et al. 2018). In the past, Planctomycetes were thought to have a number of exceptional traits (Devos et al. 2013; Devos and Reynaud 2010; Fuerst and Sagulenko 2011; Fuerst and Webb 1991; König et al. 1984; Lindsay et al. 1997; Lonhienne et al. 2010) that would place them at the base of the eukaryotes, but these properties have been re-interpreted in the recent years (Acehan et al. 2013; Boedeker et al. 2017; Jeske et al. 2015; Jogler 2014; Jogler et al. 2011; Jogler and Jogler 2013; Neumann et al. 2014; Rast et al. 2017; Rivas-Marin et al. 2016; Santarella-Mellwig et al. 2013). The cell envelope architecture of Planctomycetes was classified as Gram-negative (Boedeker et al. 2017; Devos 2014; van Teeseling et al. 2015).

Nevertheless, Planctomycetes are non-canonical as they have many remarkable properties. They perform cell division by budding or binary fission (or even a combination) while lacking most of the canonical cell division proteins, including FtsZ (Jogler et al. 2012; Pilhofer et al. 2008; Wiegand et al. 2020). Many Planctomycetes can perform a lifestyle switch between sessile mother cells and motile daughter cells (Jogler et al. 2011; Wiegand et al. 2020). They can also have unusual crateriform structures on their cell surfaces, which are visible by electron microscopy. Their periplasm is enlarged and forms large invaginations into the cytoplasm. Several planctomycetal strains are regarded as potential talented producers of as yet uncharacterised small bioactive molecules (Graça et al. 2016; Jeske et al. 2016; Wiegand et al. 2018). Many Planctomycetes possess large numbers of giant genes (Kohn et al. 2016; Reva et al. 2008) and are amongst the bacterial phyla with the highest number of predicted genes of unknown function (Overmann et al. 2017; Wiegand et al. 2018).

In this study, we describe a novel strain, Pla $110^{\mathrm{T}}$, which was isolated from polystyrene particles incubated in the Baltic Sea. The strain is part of the family Planctomycetaceae, which includes the limnic model planctomycete Planctopirus limnophila. Most of the other known members of this clade are marine bacteria.

\section{Materials and methods}

Isolation and cultivation

Strain Pla110 ${ }^{\mathrm{T}}$ was collected during a sampling campaign, in which polystyrene particles were stored in small incubators, submerged in water and incubated at the given location for 14 days. The strain characterised here was isolated from the Baltic Sea $120 \mathrm{~m}$ off the shore at Heiligendamm, Germany (54.146 N $11.843 \mathrm{E}$ ). Isolation was performed as previously described (Wiegand et al. 2020).

The strain was cultivated and analysed in $\mathrm{M} 1 \mathrm{H}$ medium supplemented with $\mathrm{N}$-acetyl-glucosamine (NAG) and artificial seawater (ASW) (M1H NAG ASW medium) as described earlier (Wiegand et al. 2020) and incubated in a shaking incubator at $28{ }^{\circ} \mathrm{C}$ and $110 \mathrm{rpm}$. Medium supplemented with $1.5 \%(\mathrm{w} / \mathrm{v})$ washed agar was used for plates.

Light microscopy and electron microscopy

Phase contrast micrographs were taken with a Nikon Eclipse Ti inverted microscope and a Nikon DS-Ri2 camera. To ensure good image quality, specimens were immobilised using a $1 \%(\mathrm{w} / \mathrm{v})$ agarose cushion and MatTek glass bottom dishes (35 mm, No. 1.5) (Boedeker et al. 2017). ImageJ (Rueden et al. 2017) was used to examine cell size by sequentially applying an Otsu threshold, a watershed, and count particles.

Field emission scanning electron microscopy was performed as described (Boersma et al. 2019). Briefly, bacteria were fixed in formaldehyde, washed, and placed on cover slips coated with poly-L-lysine solution. Cover slips were then fixed in $1 \%(\mathrm{v} / \mathrm{v})$ glutaraldehyde and washed twice before dehydrating in a graded series of acetone $(10,30,50,70,90,100 \%$ $(\mathrm{v} / \mathrm{v}))$ on ice. Samples from the $100 \%$ acetone step were brought to room temperature before placing them in fresh $100 \%$ acetone. Samples were then subjected to critical-point drying with liquid $\mathrm{CO}_{2}$ (CPD 300, Leica). Dried samples were covered with a gold/palladium (80/20) film by sputter coating (SCD 500, Bal$\mathrm{Tec})$ before examination in a field emission scanning electron microscope (Zeiss Merlin) using the Everhart Thornley HESE2 detector and the inlens SE detector in a 25:75 ratio at an acceleration voltage of $5 \mathrm{kV}$. 
Physiological analyses

Determination of the $\mathrm{pH}$ optimum for growth was performed at $28{ }^{\circ} \mathrm{C}$, with buffering agents $100 \mathrm{mM}$ 2-( $N$-morpholino)ethanesulfonic acid (MES) at $\mathrm{pH} 5$ and 6, $100 \mathrm{mM}$ (4-(2-hydroxyethyl)-1-piperazineethanesulfonic acid) (HEPES) at $\mathrm{pH}$ 7, 7.5 and 8, or $100 \mathrm{mM} \mathrm{N}$-cyclohexyl-2-aminoethanesulfonic acid (CHES) at $\mathrm{pH} 9$ and 10. Temperature optimum for growth determination was performed at $\mathrm{pH} 7.5$ with temperatures ranging from 10 to $40{ }^{\circ} \mathrm{C}$. Cell densities were inferred from optical density measurements $\left(\mathrm{OD}_{600}\right)$.

\section{Genome information}

The genome and 16S rRNA gene sequence of strain Pla1 $10^{\mathrm{T}}$ are available from GenBank under accession numbers CP036281 and MK554533, respectively. Information on genome sequencing and assembly was previously published (Wiegand et al. 2020).

\section{Phylogenetic analysis}

16S rRNA gene-based phylogeny was computed for strain Pla1 $10^{\mathrm{T}}$, the type strains of all described planctomycetal species (assessed in January 2020), all isolates recently described (Boersma et al. 2019; Kallscheuer et al. 2019a, b, c, d, 2020; Kohn et al. 2019; Peeters et al. 2019; Rensink et al. 2020; Wiegand et al. 2020) and with an outgroup of strains from outside the Planctomycetes, but part of the PVC superphylum. The alignment of 16S rRNA genes was made with SINA (Pruesse et al. 2012). Phylogenetic analysis was performed employing a maximum likelihood approach with 1,000 bootstraps, the nucleotide substitution model GTR, gamma distribution, and estimation of proportion of invariable sites using GTRGAMMAI (Stamatakis 2014).

The genomes for the genome-based analyses were gathered from GenBank, including the sequence for strain Pla1 $10^{\mathrm{T}}$. Completeness and contamination of the genome was determined using CheckM v1.0.131 (Parks et al. 2015). The average nucleotide identity (ANI) was calculated using OrthoANI (Lee et al. 2016), the average amino acid identity (AAI) was computed with the aai.rb script from the enveomics collection (Rodriguez-R and Konstantinidis 2016) and the percentage of conserved proteins (POCP) was determined as previously described (Qin et al. 2014). The rрoB nucleotide sequences (encoding the $\beta$-subunit of the DNA-dependent RNA polymerase) were taken from the genome annotations and the sequence identities were determined as described before (Bondoso et al. 2013). Upon extracting only those parts of the sequences that would have been sequenced with the described primer set, the alignment and matrix calculation was done with Clustal Omega (Sievers et al. 2011). The genus thresholds for $r p o B$ were taken from a previous study (Kallscheuer et al. 2019d).

For the multi-locus sequence analysis (MLSA), the unique single-copy core genome of all analysed genomes was determined with proteinortho5 (Lechner et al. 2011) with the 'selfblast' option enabled. The protein sequences of the resulting orthologous groups were aligned using MUSCLE v.3.8.31 (Edgar 2004). After clipping, partially aligned $C$ - and $N$-terminal regions and poorly aligned internal regions were filtered using Gblocks (Castresana 2000). The final alignment was concatenated and clustered using the maximum likelihood method implemented by RaxML (Stamatakis 2014) with the 'rapid bootstrap' method and 500 bootstrap replicates. The outgroup consisted of concatenated gene sets of strains from the order Pirellulales.

\section{Results and discussion}

Morphological and physiological analyses

Strain Pla $110^{\mathrm{T}}$ forms white colonies, while colony colours of related strains range from white to ochre (Table 1). Mature cells of strain Pla1 $10^{\mathrm{T}}$ are attached to each other by loose polar fimbriae, enabling the cells to grow in aggregates or rosettes (Fig. 1a). Fibres originate from crateriform structures, which were also observed on one of the two poles of Pla $110^{\mathrm{T}}$ cells.

When examined with phase contrast microscopy, the cells appeared to be pear-shaped and on average $1.4 \pm 0.2$ by $0.7 \pm 0.1 \mu \mathrm{m}$ in size (Fig. 1b), which is relatively elongated for a planctomycetal cell (Table 1). This characteristic makes them distinguishable from their close relatives. Typical for members of Planctomycetaceae, the cells perform cell division by polar budding. The wider side of the cell was always 


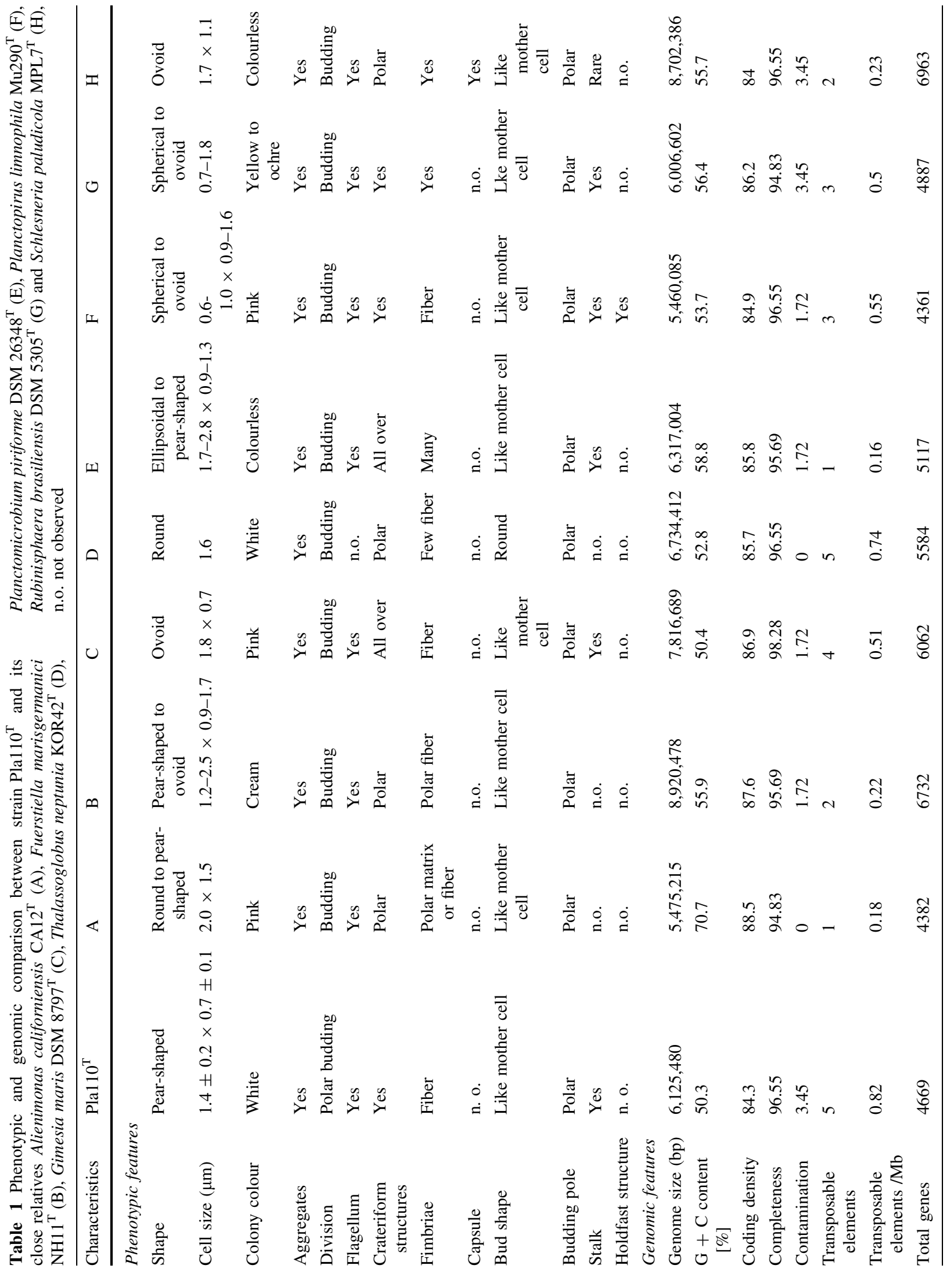




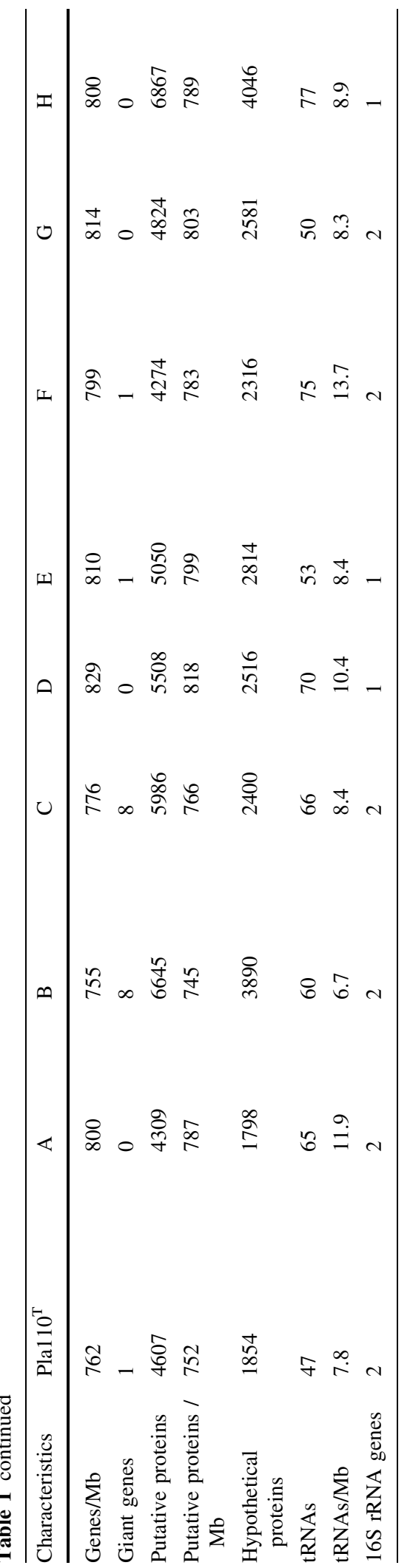

observed to be the origin of the nascent bud during both SEM and phase contrast microscopy (Fig. 1a).

Strain $\mathrm{Pla}_{110^{\mathrm{T}}}$ was isolated from the surface of plastic (polystyrene), whereas many of its close relatives were found on plant surfaces and can subsist on sugars. The strain was found to grow chemoorganotrophically, to be strictly aerobic and to grow at temperatures ranging from 10 to $27^{\circ} \mathrm{C}$, with the optimum at $24^{\circ} \mathrm{C}$ (Fig. 1b). The $\mathrm{pH}$ values that permit growth of the strain range from 6.5 to 8.5, with the optimum at 7.5 (Fig. 1b). The growth rate of this strain was calculated to be $0.033 \mathrm{~h}^{-1}$, which corresponds to a doubling time of $21 \mathrm{~h}$.

\section{Genomic characteristics}

Compared to other Planctomycetes, the genome of the novel strain features an average number of transposable elements per $\mathrm{Mb}$ (0.82). Proteins per Mb (752), genes per $\mathrm{Mb}$ (762) and tRNAs per Mb (7.67) are all at the lower end of the planctomycete spectrum (Table 1). The genome is $6,125,480 \mathrm{bp}$ in length, features two 16S rRNA genes and has a coding density of $84.5 \%$. The $\mathrm{G}+\mathrm{C}$ content of strain Pla $110^{\mathrm{T}}$ is $55.3 \%$, which is in the lower range compared to other members of the family Planctomycetaceae (50.4-70.7\%, Table 1). The number of transposable elements per $\mathrm{Mb}(0.82)$ is higher than for most of its close relatives.

Phylogenetic analysis

Based on 16S rRNA gene comparison and MLSA, strain Pla $110^{\mathrm{T}}$ clusters within the family Planctomycetaceae according to the recent re-definition (Dedysh et al. 2019) (Fig. 2). However, it remains elusive from these analyses which genus is the current closest neighbour, although both trees showed a relationship with the type strain of Gimesia maris, to which high pairwise 16S rRNA homology was found (90.5\%). The 16S rRNA sequence similarities between strain Pla110 ${ }^{\mathrm{T}}$ and the described genera within the family Planctomycetaceae range from $81.7-90.6 \%$ (Fig. 3). These identity values are below the suggested threshold for genera of $94.5 \%$ (Yarza et al. 2014), indicating that strain Pla $110^{\mathrm{T}}$ is not part of any established genus, but instead represents a novel genus.

Other phylogenetic markers, such as $r p o B$ similarity (Bondoso et al. 2013), AAI (Konstantinidis and Tiedje 2005) and POCP (Qin et al. 2014) provide 
(A)
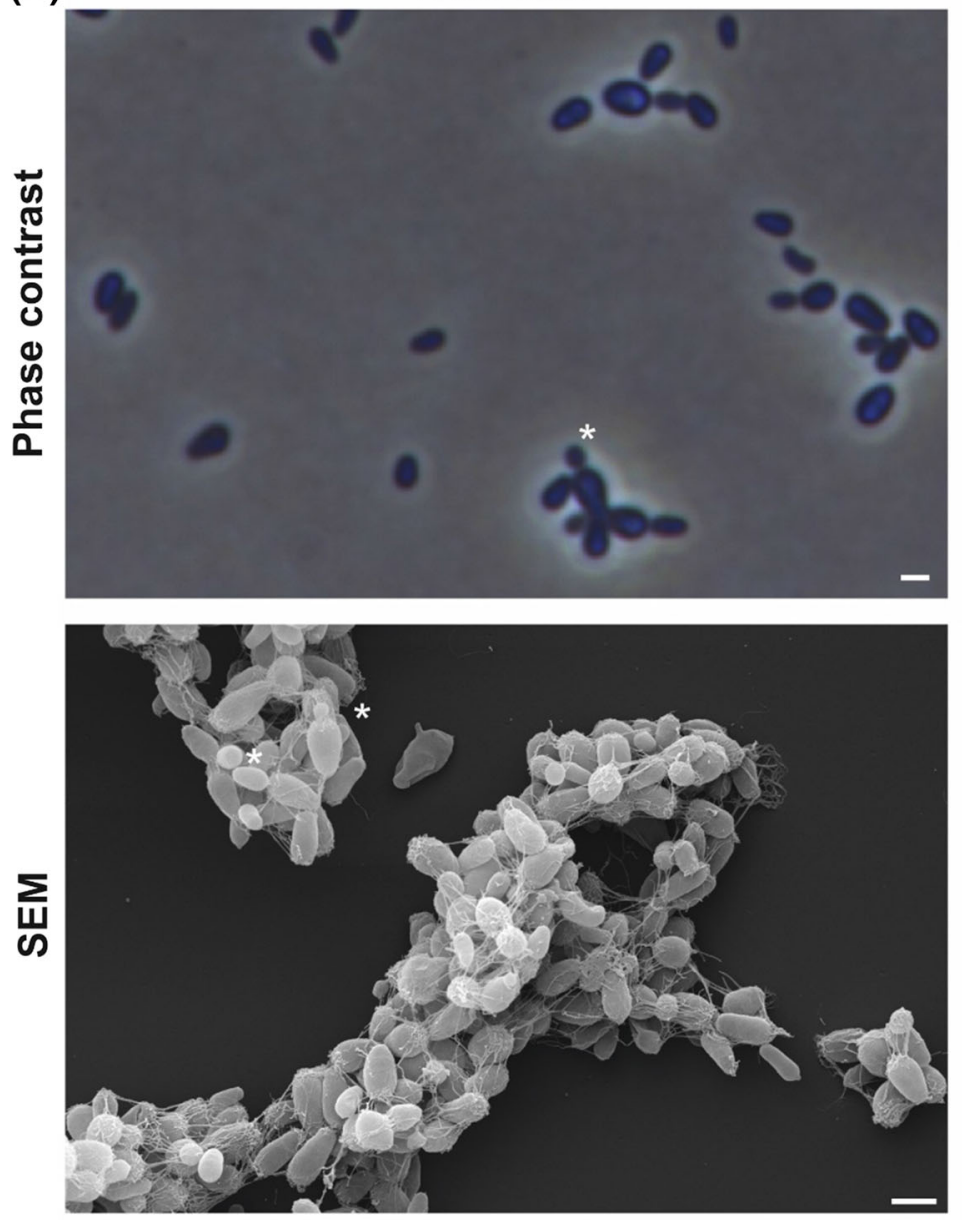

Close-up
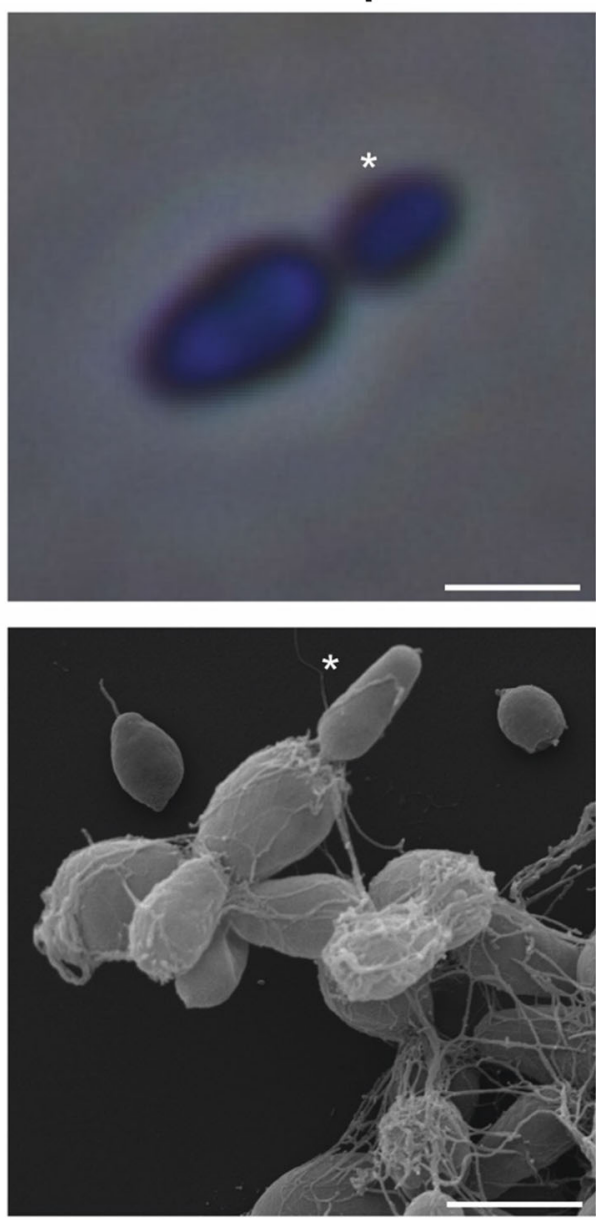

(B)

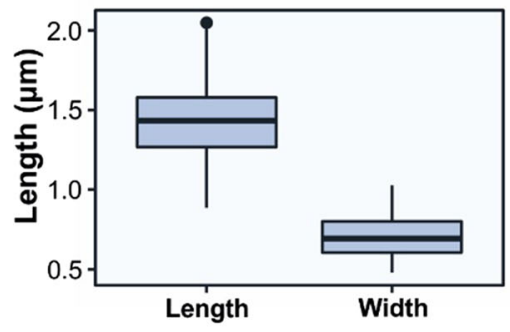

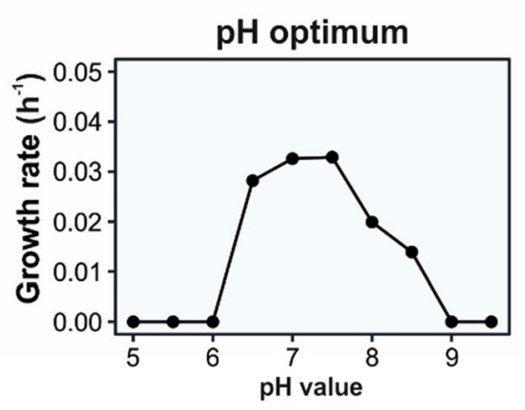

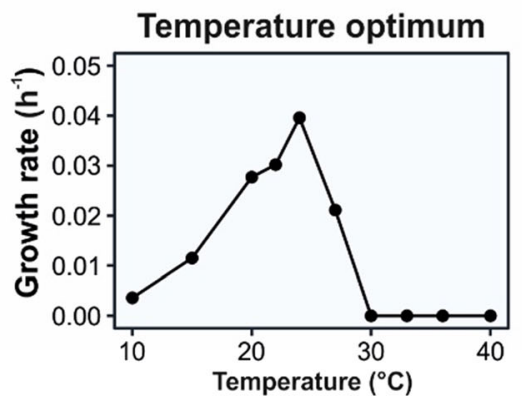

Fig. 1 Morphological and physiological characterisation of strain Pla $110^{\mathrm{T}}$ a SEM and phase contrast microscopy images showing elongated cells that divide by polar budding with the division site always at the wider side of the cell. Asterisks (*) indicate the nascent bud of a dividing cell. Scale bars represent 1 $\mu \mathrm{m}$. b Boxplot of cell size, and growth rate of strain Pla110 ${ }^{\mathrm{T}}$ at various $\mathrm{pH}$ values and temperatures

range between $48.3 \%$ and $52.8 \%$ (Fig. 3). This range falls below the threshold of $60 \%$, supporting the conclusion that this strain is indeed part of a novel genus (Luo et al. 2014). Comparison of the POCP 


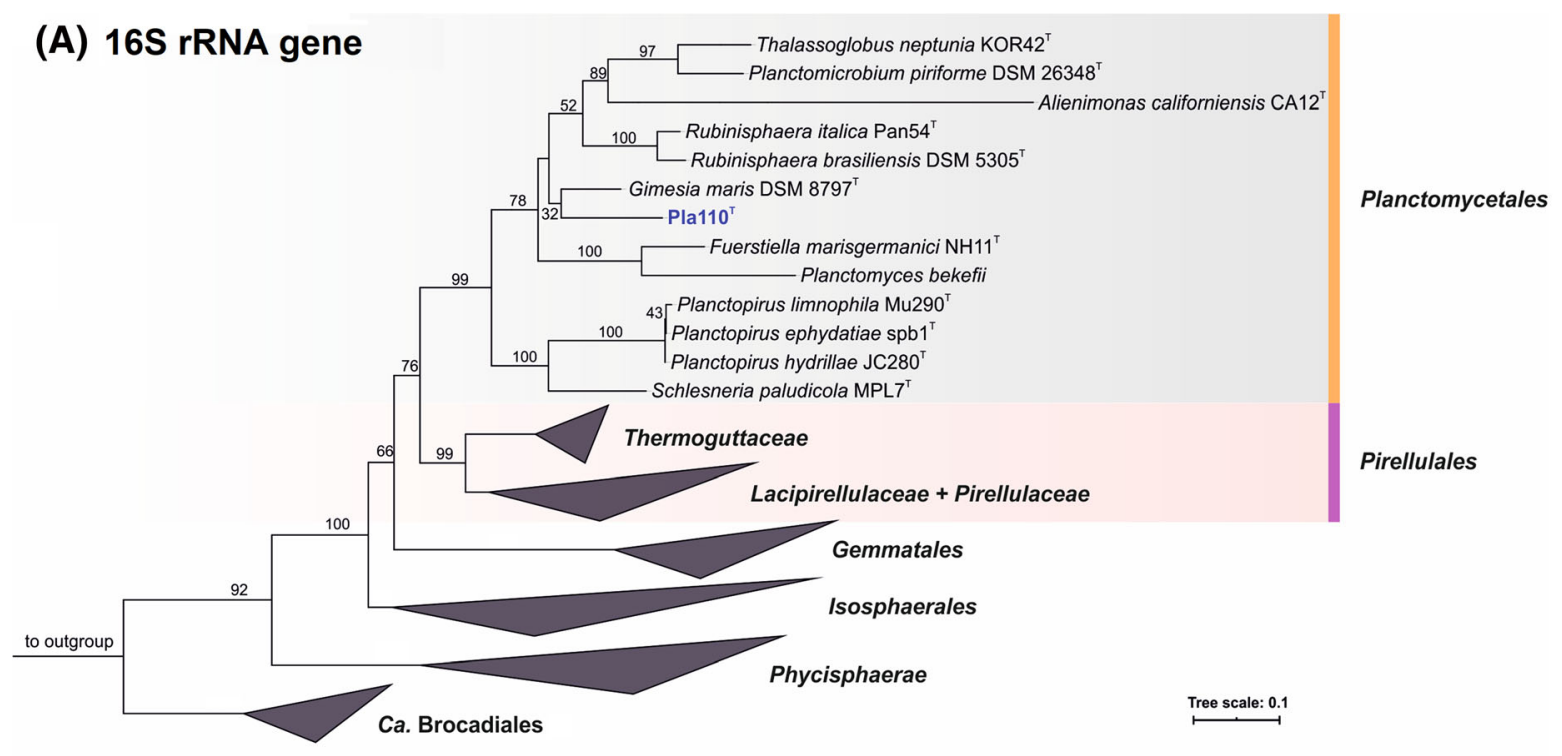

(B) MLSA

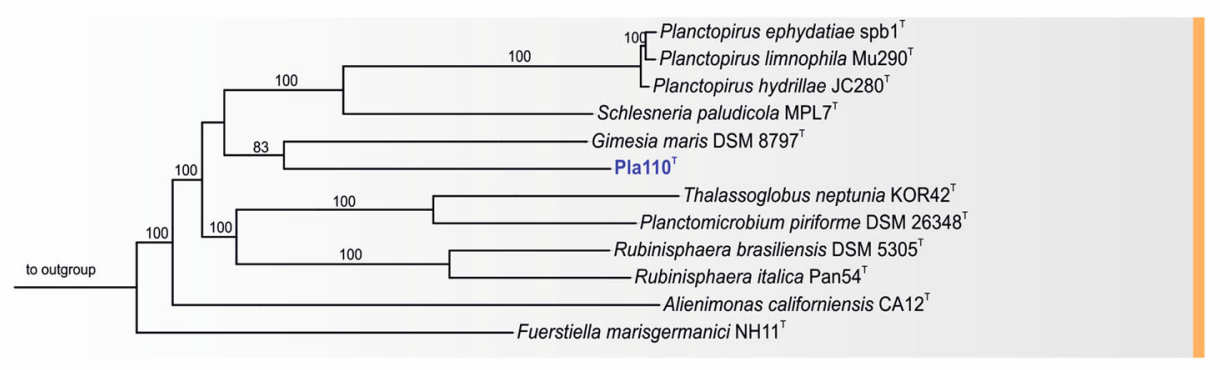

Planctomycetales

Tree scale: 0.1

Fig. 2 Phylogenetic inference of strain Pla $110^{\mathrm{T}} \mathbf{a} 16 \mathrm{~S}$ rRNA gene-based phylogenetic tree of described Planctomycetes and strain Pla $110^{\mathrm{T}}$ indicated in blue. Bootstrap values are indicated as a proportion of 1,000 re-samplings (in \%). The outgroup consists of three 16S rRNA genes from the PVC superphylum. b Whole genome-based MLSA phylogeny, with bootstrap

yielded values of $35.7-44.3 \%$ (Fig. 3), which are below the $50 \%$ cut-off value, again indicating a separate genus. The similarity of a $1200 \mathrm{bp}$ region of the $r p o B$ gene was used previously to infer phylogeny in genera belonging to the family Planctomycetaceae (Kallscheuer et al. 2019d). For the novel strain, we observed an identity of the mentioned partial sequence of the rpoB gene of $64.9-72.4 \%$ to other Planctomycetaceae members (Fig. 3). Again, these values are below the proposed threshold range for genera of $75.5-78 \%$ (Kallscheuer et al. 2019d), which is in line with the delineation of Pla $110^{\mathrm{T}}$ from existing genera. values based on 500 re-samplings at the nodes (in \%). The outgroup consists of several representatives of the order Pirellulales. Planctomyces bekefii (Dedysh et al. 2020) was included in the 16S rRNA gene-based comparison, but not in the MLSA comparison as only metagenome-assembled genomes are available

Taken together, based on results obtained for phylogeny and morphology we conclude that strain Pla1 $10^{\mathrm{T}}$ belongs to a novel genus. We propose the name Polystyrenella gen. nov., with Polystyrenella longa sp. nov. as type species. Pla $110^{\mathrm{T}}$ is the type strain of Polystyrenella longa.

Polystyrenella gen. nov.

Polystyrenella (Po.ly.sty.re.nel'la. N.L. neut. n. polystyrenum polystyrene; N.L. fem. dim. n. Polystyrenella an organism isolated from polystyrene). 


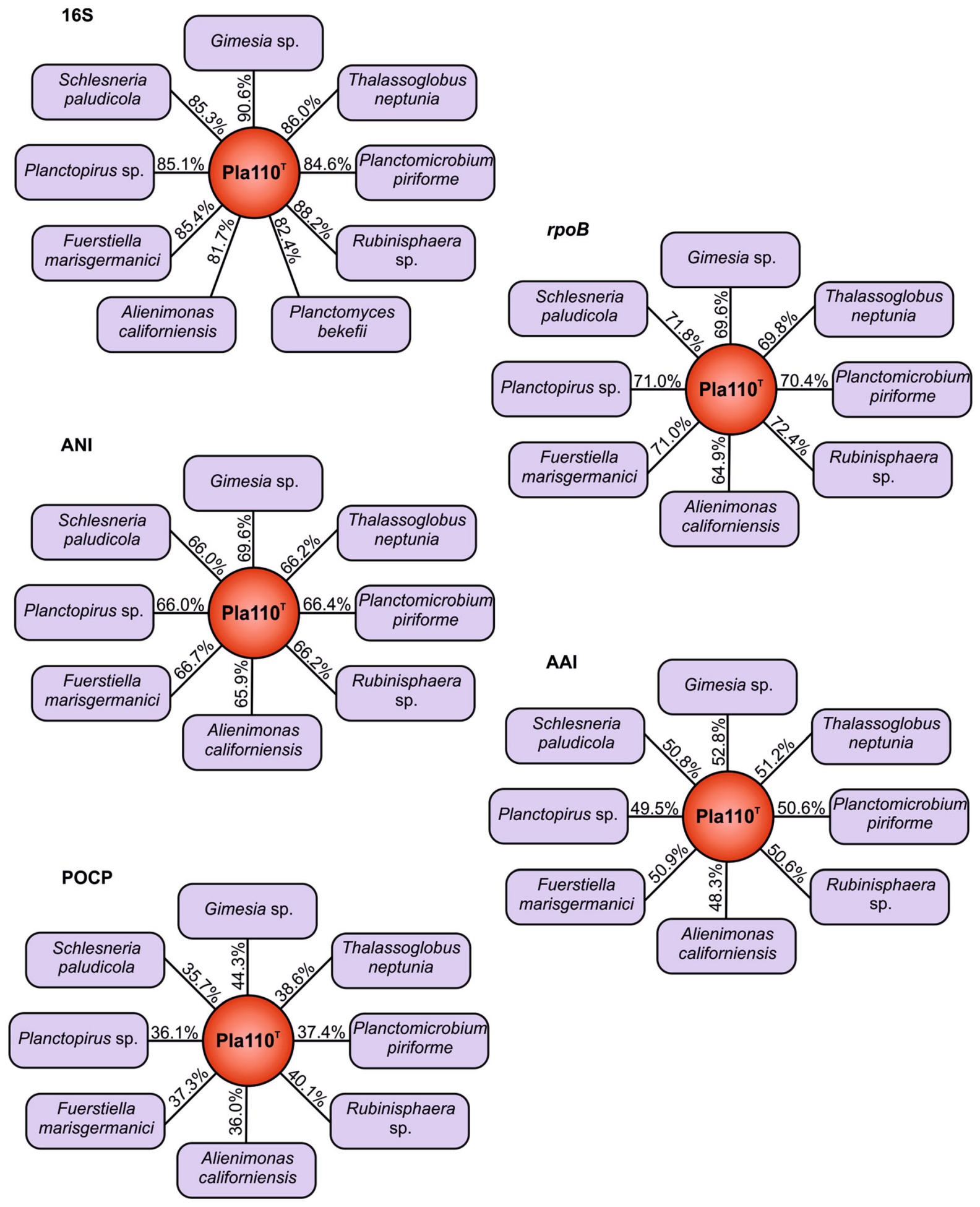


४Fig. 3 Comparison of phylogenetic markers to separate species and generaTo determine strain Pla $110^{\mathrm{T}}$ as a novel genus and species, the strain was compared to several related strains. Methods used: 16S rRNA gene sequence identity (16S), average amino acid identity (AAI), rpoB gene identity, average nucleotide identity (ANI), and percentage of conserved proteins (POCP). Planctomyces bekefii (Dedysh et al. 2020) was included in the 16S rRNA gene comparisons, but not in the others as only metagenomic bins are available

The members of this genus have a Gram-negative cell envelope architecture, are aerobic, mesophilic, neutrophilic and heterotrophic. Cells are pear-shaped and divide by polar budding. The genus is part of the family Planctomycetaceae, order Planctomycetales, class Planctomycetia, phylum Planctomycetes.

\section{Polystyrenella longa sp. nov.}

Polystyrenella longa (lon'ga. L. fem. adj. longa long; corresponding to the longish appearance of the cells).

The members of this species are pear-shaped cells that grow in aggregates or rosettes. The cells are between $1.4 \pm 0.2$ by $0.7 \pm 0.1 \mu \mathrm{m}$ in size and divide by polar budding. The cells produce fimbriae originating from one of the cell poles, and have crateriform structures on this fibre pole. The type strain grows at 10-27 ${ }^{\circ} \mathrm{C}$ (optimum $24^{\circ} \mathrm{C}$ ) and $\mathrm{pH} 6.5-8.5$ (optimum 7.5). Forms white colonies on M1H NAG ASW agar. The $\mathrm{G}+\mathrm{C}$ content of the type strain genome is $50.3 \%$.

The type strain, Pla110 ${ }^{\mathrm{T}}\left(\mathrm{DSM} 103387^{\mathrm{T}}=\mathrm{LMG}\right.$ $29693^{\mathrm{T}}$ ), was isolated from polystyrene particles submerged near Heiligendamm in the Baltic Sea. The genome (accession no. CP036281) and 16S rRNA gene sequence (accession no. MK554533) are available from GenBank.

Acknowledgements Open Access funding provided by Projekt DEAL. Part of this research was funded by the Deutsche Forschungsgemeinschaft grants KA 4967/1-1 and JO 893/4 - 1, Grant ALWOP.308 of the Nederlandse Organisatie voor Wetenschappelijk Onderzoek (NWO), SIAM (Soehngen Institute for Anaerobic Microbiology) Grant No. 024002002 and the Radboud Excellence fellowship. We thank Ina Schleicher for skillful technical assistance. Brian Tindall and Regine Fähnrich from the DSMZ as well as the BCCM/ LMG Bacteria collection we thank for support during strain deposition. We thank our collaborators Sonja Oberbeckmann and Matthias Labrenz (IOW Warnemünde, Germany) for sampling support.
Author contributions S.H.P. and S.W. wrote the manuscript, analysed the data and prepared the figures, S.W. performed the genomic and phylogenetic analysis, A.H. and M.J. isolated the strains and performed the initial cultivation and strain deposition, S.H.P. and C.B. performed the light microscopic analysis, N.K. and M.S.M.J. contributed to text preparation and revised the manuscript, M.R. performed the electron microscopic analysis. C.J. supervised A.H. and the study. All authors read and approved the final version of the manuscript.

\section{Compliance with ethical standards}

Conflict of interest The authors declare that they have no conflict of interest.

Ethicals statement This article does not contain any studies with animals performed by any of the authors.

Open Access This article is licensed under a Creative Commons Attribution 4.0 International License, which permits use, sharing, adaptation, distribution and reproduction in any medium or format, as long as you give appropriate credit to the original author(s) and the source, provide a link to the Creative Commons licence, and indicate if changes were made. The images or other third party material in this article are included in the article's Creative Commons licence, unless indicated otherwise in a credit line to the material. If material is not included in the article's Creative Commons licence and your intended use is not permitted by statutory regulation or exceeds the permitted use, you will need to obtain permission directly from the copyright holder. To view a copy of this licence, visit http://creativecommons.org/licenses/by/4.0/.

\section{References}

Acehan D, Santarella-Mellwig R, Devos DP (2013) A bacterial tubulovesicular network. J Cell Sci 127:277-280

Bengtsson MM, Øvreås L (2010) Planctomycetes dominate biofilms on surfaces of the kelp Laminaria hyperborea. BMC Microbiol 10:261

Bengtsson MM, Sjøtun K, Lanzén A, Øvreås L (2012) Bacterial diversity in relation to secondary production and succession on surfaces of the kelp Laminaria hyperborea. ISME J 6:2188-2198

Boedeker C, Schuler M, Reintjes G, Jeske O, van Teeseling MC, Jogler M, Rast P, Borchert D, Devos DP, Kucklick M, Schaffer M, Kolter R, van Niftrik L, Engelmann S, Amann R, Rohde M, Engelhardt H, Jogler C (2017) Determining the bacterial cell biology of Planctomycetes. Nat Commun $8: 14853$

Boersma A, Kallscheuer N, Wiegand S, Rast R, Peeters S, Mesman R, Heuer A, Boedeker C, Jetten M, Rohde M, Jogler M, Jogler C (2019) Alienimonas californiensis gen. nov. sp. nov., a novel Planctomycete isolated from the kelp forest in Monterey Bay. Antonie van Leeuwenhoek. https:// doi.org/10.1007/s10482-019-01367-4 
Bondoso J, Harder J, Lage OM (2013) rpoB gene as a novel molecular marker to infer phylogeny in Planctomycetales. Antonie van Leeuwenhoek 104:477-488

Bondoso J, Balague V, Gasol JM, Lage OM (2014) Community composition of the Planctomycetes associated with different macroalgae. FEMS Microbiol Ecol 88:445-456

Bondoso J, Albuquerque L, Nobre MF, Lobo-da-Cunha A, da Costa MS, Lage OM (2015) Roseimaritima ulvae gen. nov., sp. nov. and Rubripirellula obstinata gen. nov., sp. nov. two novel planctomycetes isolated from the epiphytic community of macroalgae. Syst Appl Microbiol 38:8-15

Bondoso J, Godoy-Vitorino F, Balague V, Gasol JM, Harder J, Lage OM (2017) Epiphytic Planctomycetes communities associated with three main groups of macroalgae. FEMS Microbiol Ecol 93:fiw255

Castresana J (2000) Selection of conserved blocks from multiple alignments for their use in phylogenetic analysis. Mol Biol Evol 17:540-552

Dedysh SN, Kulichevskaya IS, Beletsky AV, Ivanova AA, Rijpstra WIC, Damsté JSS, Mardanov AV, Ravin NV (2019) Lacipirellula parvula gen. nov., sp. nov., representing a lineage of planctomycetes widespread in lowoxygen habitats, description of the family Lacipirellulaceae fam. nov. and proposal of the orders Pirellulales ord. nov., Gemmatales ord. nov. and Isosphaerales ord. nov. Syst Appl Microbiol 43: 126050

Dedysh SN, Henke P, Ivanova AA, Kulichevskaya IS, Philippov DA, Meier-Kolthoff JP, Goker M, Huang S, Overmann J (2020) 100-year-old enigma solved: identification, genomic characterization and biogeography of the yet uncultured Planctomyces bekefii. Environ Microbiol 22:198-211

Devos DP, Reynaud EG (2010) Evolution. Intermediate steps. Science 330:1187-1188

Devos DP, Jogler C, Fuerst JA (2013) The 1st EMBO workshop on PVC bacteria-Planctomycetes-Verrucomicrobia-Chlamydiae superphylum: exceptions to the bacterial definition? Antonie Van Leeuwenhoek 104:443-449

Devos DP (2014) PVC bacteria: variation of, but not exception to, the Gram-negative cell plan. Trends Microbiol 22:14-20

Edgar RC (2004) MUSCLE: multiple sequence alignment with high accuracy and high throughput. Nucleic Acids Res 32:1792-1797

Frank O, Michael V, Pauker O, Boedeker C, Jogler C, Rohde M, Petersen J (2014) Plasmid curing and the loss of grip - The 65-kb replicon of Phaeobacter inhibens DSM 17395 is required for biofilm formation, motility and the colonization of marine algae. Syst Appl Microbiol 38:120-127

Fuerst JA, Sagulenko E (2011) Beyond the bacterium: Planctomycetes challenge our concepts of microbial structure and function. Nat Rev Microbiol 9:403-413

Fuerst JA, Webb RI (1991) Membrane-bounded nucleoid in the eubacterium Gemmata obscuriglobus. Proc Natl Acad Sci USA 88:8184-8188

Graça AP, Calisto R, Lage OM (2016) Planctomycetes as Novel Source of Bioactive Molecules. Front Microbiol 7:1241

Jeske O, Jogler M, Petersen J, Sikorski J, Jogler C (2013) From genome mining to phenotypic microarrays: Planctomycetes as source for novel bioactive molecules. Antonie Van Leeuwenhoek 104:551-567
Jeske O, Schüler M, Schumann P, Schneider A, Boedeker C, Jogler M, Bollschweiler D, Rohde M, Mayer C, Engelhardt H, Spring S, Jogler C (2015) Planctomycetes do possess a peptidoglycan cell wall. Nat Commun 6:7116

Jeske O, Surup F, Ketteniß M, Rast P, Förster B, Jogler M, Wink J, Jogler C (2016) Developing techniques for the utilization of Planctomycetes as producers of bioactive molecules. Front Microbiol 7:1242

Jogler C, Glöckner FO, Kolter R (2011) Characterization of Planctomyces limnophilus and development of genetic tools for its manipulation establish it as a model species for the phylum Planctomycetes. Appl Environ Microbiol 77:5826-5829

Jogler C, Waldmann J, Huang X, Jogler M, Glöckner FO, Mascher T, Kolter R (2012) Identification of proteins likely to be involved in morphogenesis, cell division, and signal transduction in Planctomycetes by comparative genomics. J Bacteriol 194:6419-6430

Jogler M, Jogler C (2013) Towards the development of genetic tools for Planctomycetes. In: Fuerst JA (ed) Planctomycetes: cell structure, origins and biology. Springer, Berlin, pp 141-164

Jogler C (2014) The bacterial 'mitochondrium'. Mol Microbiol 94:751-755

Kallscheuer N, Jogler M, Wiegand S, Peeters SH, Heuer A, Boedeker C, Jetten MS, Rohde M, Jogler C (2019a) $R u$ binisphaera italica sp. nov. isolated from a hydrothermal area in the Tyrrhenian Sea close to the volcanic island Panarea. Antonie van Leeuwenhoek, https://doi.org/10. 1007/s10482-019-01329-w

Kallscheuer N, Jogler M, Wiegand S, Peeters SH, Heuer A, Boedeker C, Jetten MS, Rohde M, Jogler C (2019b) Three novel Rubripirellula species isolated from plastic particles submerged in the Baltic Sea and the estuary of the river Warnow in northern Germany. Antonie van Leeuwenhoek. https://doi.org/10.1007/s10482-019-01368-3

Kallscheuer N, Wiegand S, Jogler M, Boedeker C, Peeters SH, Rast P, Heuer A, Jetten MSM, Rohde M, Jogler C (2019c) Rhodopirellula heiligendammensis sp. nov., Rhodopirellula pilleata sp. nov., and Rhodopirellula solitaria sp. nov. isolated from natural or artificial marine surfaces in Northern Germany and California, USA, and emended description of the genus Rhodopirellula. Antonie van Leeuwenhoek, https://doi.org/10.1007/s10482-019-013665

Kallscheuer N, Wiegand S, Peeters SH, Jogler M, Boedeker C, Heuer A, Rast P, Jetten MSM, Rohde M, Jogler C (2019d) Description of three bacterial strains belonging to the new genus Novipirellula gen. nov., reclassificiation of Rhodopirellula rosea and Rhodopirellula caenicola and readjustment of the genus threshold of the phylogenetic marker rpoB for Planctomycetaceae. Antonie van Leeuwenhoek, https://doi.org/10.1007/s10482-019-01374-5

Kallscheuer N, Wiegand S, Heuer A, Rensink S, Boersma AS, Jogler M, Boedeker C, Peeters SH, Rast P, Jetten MS, Rohde M, Jogler C (2020) Blastopirellula retiformator $\mathrm{sp}$. nov. isolated from the shallow-sea hydrothermal vent system close to Panarea Island. Antonie van Leeuwenhoek. https://doi.org/10.1007/s10482-019-01377-2

Kohn T, Heuer A, Jogler M, Vollmers J, Boedeker C, Bunk B, Rast P, Borchert D, Glöckner I, Freese HM, Klenk HP, 
Overmann J, Kaster AK, Wiegand S, Rohde M, Jogler C (2016) Fuerstia marisgermanicae gen. nov., sp. nov., an unusual member of the phylum Planctomycetes from the German Wadden Sea. Front Microbiol 7: 2079

Kohn T, Wiegand S, Boedeker C, Rast P, Heuer A, Jetten M, Schüler M, Becker S, Rohde C, Müller R-W, Rohde M, Engelhardt H, Jogler M, Jogler C (2019) Planctopirus ephydatiae, a novel Planctomycete isolated from a freshwater sponge. Syst Appl Microbiol 43:126022

König E, Schlesner H, Hirsch P (1984) Cell wall studies on budding bacteria of the Planctomyces/Pasteuria group and on a Prosthecomicrobium sp. Arch Microbiol 138:200-205

Konstantinidis KT, Tiedje JM (2005) Genomic insights that advance the species definition for prokaryotes. Proc Natl Acad Sci USA 102:2567-2572

Konstantinidis Rodriguez-R,LM, KT (2016) The enveomics collection: a toolbox for specialized analyses of microbial genomes and metagenomes. PeerJ Preprints 4: e1900v1

Kulichevskaya IS, Serkebaeva YM, Kim Y, Rijpstra IC, Sinninghe Damste JS, Liesack W, Dedysh SN (2012) Telmatocola sphagniphila gen. nov., sp. nov., a novel dendriform planctomycete from northern wetlands. Front Microbiol 3:146

Lachnit T, Fischer M, Kunzel S, Baines JF, Harder T (2013) Compounds associated with algal surfaces mediate epiphytic colonization of the marine macroalga Fucus vesiculosus. FEMS Microbiol Ecol 84:411-420

Lage OM, Bondoso J (2014) Planctomycetes and macroalgae, a striking association. Front Microbiol 5:267

Lechner M, Findeiss S, Müller L, Marz M, Stadler P, Prohaska S (2011) Proteinortho: Detection of (Co)Orthologs in LargeScale Analysis. BMC Bioinformatics 12:124

Lee I, Ouk Kim Y, Park SC, Chun J (2016) OrthoANI: An improved algorithm and software for calculating average nucleotide identity. Int $\mathrm{J}$ Syst Evol Microbiol 66:1100-1103

Lindsay MR, Webb RI, Fuerst JA (1997) Pirellulosomes: A new type of membrane-bounded cell compartment in planctomycete bacteria of the genus Pirellula. Microbiology-UK 143:739-748

Lonhienne TG, Sagulenko E, Webb RI, Lee KC, Franke J, Devos DP, Nouwens A, Carroll BJ, Fuerst JA (2010) Endocytosis-like protein uptake in the bacterium Gemmata obscuriglobus. Proc Natl Acad Sci USA 107:12883-12888

Luo C, Rodriguez RL, Konstantinidis KT (2014) MyTaxa: an advanced taxonomic classifier for genomic and metagenomic sequences. Nucleic Acids Res 42:e73

Neumann S, Wessels HJ, Rijpstra WI, Sinninghe Damste JS, Kartal B, Jetten MS, van Niftrik L (2014) Isolation and characterization of a prokaryotic cell organelle from the anammox bacterium Kuenenia stuttgartiensis. Mol Microbiol 94:794-802

Overmann J, Abt B, Sikorski J (2017) Present and Future of Culturing Bacteria. Annu Rev Microbiol 71:711-730

Parks DH, Imelfort M, Skennerton CT, Hugenholtz P, Tyson GW (2015) CheckM: assessing the quality of microbial genomes recovered from isolates, single cells, and metagenomes. Genome Res 25:1043-1055

Peeters SH, van Niftrik L (2018) Trending topics and open questions in anaerobic ammonium oxidation. Curr Opin Chem Biol 49:45-52
Peeters SH, Wiegand S, Kallscheuer N, Jogler M, Heuer A, Jetten MSM, Rast P, Boedeker C, Rohde M, Jogler C (2019) Three marine strains constitute the novel genus and species Crateriforma conspicua in the phylum Planctomycetes. Antonie van Leeuwenhoek. https://doi.org/10. 1007/s10482-019-01375-4

Pilhofer M, Rappl K, Eckl C, Bauer AP, Ludwig W, Schleifer KH, Petroni G (2008) Characterization and evolution of cell division and cell wall synthesis genes in the bacterial phyla Verrucomicrobia, Lentisphaerae, Chlamydiae, and Planctomycetes and phylogenetic comparison with rRNA genes. J Bacteriol 190:3192-3202

Pruesse E, Peplies J, Glöckner FO (2012) SINA: accurate highthroughput multiple sequence alignment of ribosomal RNA genes. Bioinformatics 28:1823-1829

Qin QL, Xie BB, Zhang XY, Chen XL, Zhou BC, Zhou J, Oren A, Zhang YZ (2014) A proposed genus boundary for the prokaryotes based on genomic insights. J Bacteriol 196:2210-2215

Rast P, Glockner I, Boedeker C, Jeske O, Wiegand S, Reinhardt R, Schumann P, Rohde M, Spring S, Glockner FO, Jogler C, Jogler M (2017) Three Novel Species with Peptidoglycan Cell Walls form the New Genus Lacunisphaera gen. nov. in the Family Opitutaceae of the Verrucomicrobial Subdivision 4. Front Microbiol 8:202

Rensink S, Wiegand S, Kallscheuer N, Rast P, Peeters SH, Heuer A, Boedeker C, Jetten MS, Rohde M, Jogler M, Jogler C (2020) Description of the novel planctomycetal genus Bremerella, containing Bremerella volcania sp. nov., isolated from an active volcanic site, and reclassification of Blastopirellula cremea as Bremerella cremea comb. nov. Antonie van Leeuwenhoek, https://doi.org/10. 1007/s10482-019-01378-1

Reva O, Tümmler B (2008) Think big-giant genes in bacteria. Environ Microbiol 10:768-777

Rivas-Marin E, Canosa I, Santero E, Devos DP (2016) Development of Genetic Tools for the Manipulation of the Planctomycetes. Front Microbiol 7:914

Rueden CT, Schindelin J, Hiner MC, DeZonia BE, Walter AE, Arena ET, Eliceiri KW (2017) ImageJ2: ImageJ for the next generation of scientific image data. BMC Bioinformatics 18:529

Santarella-Mellwig R, Pruggnaller S, Roos N, Mattaj IW, Devos DP (2013) Three-dimensional reconstruction of bacteria with a complex endomembrane system. PLoS Biol 11:e1001565

Sievers F, Wilm A, Dineen D, Gibson TJ, Karplus K, Li W, Lopez R, McWilliam H, Remmert M, Söding J (2011) Fast, scalable generation of high-quality protein multiple sequence alignments using Clustal Omega. Mol Syst Biol 7:539

Slobodkina GB, Kovaleva OL, Miroshnichenko ML, Slobodkin AI, Kolganova TV, Novikov AA, van Heerden E, BonchOsmolovskaya EA (2015) Thermogutta terrifontis gen. nov., sp. nov. and Thermogutta hypogea sp. nov., thermophilic anaerobic representatives of the phylum Planctomycetes. Int J Syst Evol Microbiol 65:760-765

Stamatakis A (2014) RAxML version 8: a tool for phylogenetic analysis and post-analysis of large phylogenies. Bioinformatics 30:1312-1313 
Strous M, Fuerst JA, Kramer EH, Logemann S, Muyzer G, van de Pas-Schoonen KT, Webb R, Kuenen JG, Jetten MS (1999) Missing lithotroph identified as new planctomycete. Nature 400:446-449

van Teeseling MC, Mesman RJ, Kuru E, Espaillat A, Cava F, Brun YV, VanNieuwenhze MS, Kartal B, van Niftrik L (2015) Anammox Planctomycetes have a peptidoglycan cell wall. Nat Commun 6:6878

Vollmers J, Frentrup M, Rast P, Jogler C, Kaster AK (2017) Untangling Genomes of Novel Planctomycetal and Verrucomicrobial Species from Monterey Bay Kelp Forest Metagenomes by Refined Binning. Front Microbiol 8:472

Wagner M, Horn M (2006) The Planctomycetes, Verrucomicrobia, Chlamydiae and sister phyla comprise a superphylum with biotechnological and medical relevance. Curr Opin Biotechnol 17:241-249

Wiegand S, Jogler M, Jogler C (2018) On the maverick Planctomycetes. FEMS Microbiol Rev 42:739-760

Wiegand S, Jogler M, Boedeker C, Pinto D, Vollmers J, RivasMarín E, Kohn T, Peeters SH, Heuer A, Rast P, Oberbeckmann S, Bunk B, Jeske O, Meyerdierks A, Storesund JE, Kallscheuer N, Lücker S, Lage OM, Pohl T, Merkel BJ,
Hornburger P, Müller R-W, Brümmer F, Labrenz M, Spormann AM, Op den Camp HJM, Overmann J, Amann R, Jetten MSM, Mascher T, Medema MH, Devos DP, Kaster A-K, Øvreås, L, Rohde, M, Galperin, MY, Jogler, C, 2019. Cultivation and functional characterization of 79 planctomycetes uncovers their unique biology. Nature Microbiology.Wiegand, Jogler S, M, Boedeker, C, Pinto, D, Vollmers, J, Rivas-Marín, E, Kohn, T, Peeters, SH, Heuer, A, Rast, P (2020) Cultivation and functional characterization of 79 Planctomycetes uncovers their unique biology. Nat Microbiology 5: 126-140

Yarza P, Yilmaz P, Pruesse E, Glöckner FO, Ludwig W, Schleifer K-H, Whitman WB, Euzéby J, Amann R, RossellóMóra R (2014) Uniting the classification of cultured and uncultured bacteria and archaea using 16S rRNA gene sequences. Nat Rev Microbiol 12:635

Publisher's Note Springer Nature remains neutral with regard to jurisdictional claims in published maps and institutional affiliations. 